\title{
Multipl Miyelom Patogenezinde Puma ve P53'ün Öneminin Değerlendirilmesi
}

\section{Evalution of The Puma and P53 Significance in Multiple Myelom}

İsmail Baloğlu

Aynur Uğur Bilgin²

Necmettin Erbakan Universitesi, Ic Hastalıkları Anabilim Dalı, Nefroloji Bilim Dalı Konya, Türkiye

${ }^{2}$ Özel Koru Hastanesi, Hematoloji Bilim Dalı, Ankara, Türkiye

Geliş Tarihi/Received: 6 Haziran 2018 Kabul Tarihi/Accepted: 13 Eylül 2018

Yazışma Adresi: İsmail Baloğlu, Necmettin Erbakan Universitesi, İç hastalıkları Anabilim Dalı, Nefroloji Bilim Dalı Konya e-mail: i_baloglu@hotmail.com

\section{ORCID}

İsmail Baloğlu

https://orcid.org/0000-0002-8751-5490

\begin{abstract}
Öz
Amaç: Multipl miyelom (MM) patogenezi tam olarak bilinmeyen bir hastalıktır. Konuyla ilgili farkl hipotezlerde ileri sürülse de son zamanlarda apopitozis yolaklarındaki mutasyonlar ön plana çıkmaktadır. PUMA p53 ile ilişkili veya ilişkisiz olarak transkripsiyon faktörlerince düzenlenen çeşitli sinyallerle apopitozisde rol alabilir. Bu çalışmada; p53 ve PUMA ekspresyonlarını çalışılmış ve p53-PUMA ekspresyonu ile hastalık patogenezi arasında bir ilişki aranmıştır.

Hastalar ve Yöntem: p53 ve PUMA ekspresyonları immünohistokimyasal yöntemle değerlendirildi. İşlem p53 ve PUMA'ya karşı spesifik antikor kullanılarak gerçekleştirildi. MM hastalarının tanı anındaki kemik iliği biyopsiler örnekleri $(n=31)$ çalıșma grubu olarak alındı. Normal hematopoez tespit edilen kemik iliği biyopsileri $(n=12)$ kontrol grubu olarak alındı. Boyandıktan sonra pozitif boyanan her bir örneğin boyanma kuvveti hesaplandı.

Bulgular: MM hastalarının kemik iliklerinde PUMA ekspresyonu gösteren hücrelerin yüzdesi, norma bireylerin kemik iliklerine göre önemli ölçüde yüksekti $(p=0.000)$. Plazma hücre yüzdesi ile PUMA boyanma yaygınlığı arasında istatiksel olarak anlamlı olmasa da bir ilişki mevcuttu $(p=0.385)$. PUMA ekspresyonları ile hastalığın evresi arasında bir ilişki yoktu.

Sonuç: Sonuçlarımız, MM hastalarının kemik iliği örneklerinde özellikle PUMA ekspresyonunun, sağlıklı kontrollere göre önemli ölçüde daha yüksek olduğunu gösterdi. PUMA pozitifliğinin p53' e oranla daha fazla olması tanı anında PUMA' nın nongentoksik nedenlerle indüklendiğini düşündürdü. p53 ve PUMA pozitifliğinin kontrol grubuna göre yüksek olması miyelom patogenezinde apopitozisin rol oynadığını
\end{abstract} düşündürmektedir.

Anahtar Kelimeler: Multipl miyelom, apopitozis, PUMA, p53

\begin{abstract}
Aim: Multipl myeloma is a disease of unknown pathogenesis. Although there was a different hypotheses on the subject, recently mutations in the pathway of apoptosis come to the fore. PUMA may play a role in apoptosis, bound or unbound p53. The role is regulated by various signals of transcription factors. In this study; the expressions of p53 and PUMA in bone marrow hematopoetic cells of have been worked and the relationship between myeloma pathogenesis with p53- PUMA was searched.

Patients and Methods: The expression of p53 and PUMA was evaluated using immunohistochemistry. The procedure was carried out using specific antibodies against p53 and PUMA. Bone marrow biopsies of MM patients at the time of diagnosis $(n=31)$ were included in the study group. Bone marrow biopsies from individuals who had normal hematopoiesis $(n=12)$ were included as control. After staining, strength was calculated of each positively staining cells

Results: The percentage of cells showing PUMA expression was significantly higher in bone marrows of MM patients as compared to normal bone marrow samples $(p=0.000)$. We found a correlation between the percentage of plasma cells with staining prevalence of PUMA, but it was not statistically significant $(p=0.385)$. There was no correlation between the stage of the disease with PUMA expression.

Conclusion: Our results showed that specially PUMA expression is significantly higher in bone marrow cells of MM patients compared to healthy controls. Higher positivity of PUMA suggested that, PUMA induced nongenotoxic reasons at the time of diagnosis. The lack of p53 and PUMA positivite suggests that, apoptosis play a role in myeloma pathogenesis.
\end{abstract}

Key words: Multiple myeloma, apoptosis, PUMA, p53

\section{GíRiş}

Multipl myelom anemi, tekrarlayan enfeksiyonlar, serum ve / veya idrar monoklonal protein, osteolitik kemik lezyonları, hiperkalsemi ve böbrek yetmezliği ile karakterize bir plazma hücresi malignitesidir (1). MM, patogenezi bilinmeyen bir hastalıktır. Konuyla ilgili farklı bir hipotez olmasına rağmen son zamanlarda apoptoz yolundaki mutasyonlar öne çıkmaktadır. Apopitozis biyolojik sistemlerde yaygın olarak meydana gelen, fazlalık halindeki veya istenmeyen hücreleri kontrol altında tutan, programlı hücre ölümüdür. (2). Bu süreçte rol oynayan p53 ve PUMA, Bcl- 2 aracılığı ile fonksiyon gösterir ve temel olarak apopitozisin gerçekleşmesini sağlar. Hematopoez üzerinde yetersiz apopitozis etkisi lösemi gibi neoplazilerin gelişimine neden olabilirken, artmış

Atıf Yapmak İçin: Baloğlu İ, Bilgin AU. Multipl Miyelom Patogenezinde Puma ve P53'ün Öneminin Değerlendirilmesi. Selcuk Med J 2019;35(2): 94-98 
apopitozis kemik iliği yetersizliğine ve sitopenilere yol açabilmektedir (3).

P53 tümör supresör geni apopitoziste önemli bir göreve sahiptir. P53, proapopitotik $\mathrm{Bcl}-2$ genlerinin transkripsiyonal upregülasyonu aracılığıyla hücre siklus ölümü, DNA onarımı ve apopitozis dahil olmak üzere birkaç yolağı düzenleyici fonksiyon gösterir (4). PUMA ise bcl-2 protein ailesinin bir üyesi olup bcl-2 bağlayıc komponent 3 olarak da bilinir. PUMA ekspresyonu bir tümör süpresör gen olan p 53 tarafından düzenlenir (5). PUMA, p53 ile ilişkili veya ilişkisiz olarak transkripsiyon faktörlerince düzenlenen çeşitli sinyallerle apopitozisde rol alabilir. PUMA, eksprese edildiğinde, birkaç saat içinde kanser hücrelerinin ölümüne yol açar (6). Multipl miyelomda apopitozis ile ilgili çalışmalar bulunsa da daha önce PUMA ile ilgili yeterli çalışma bulunmamaktadır. Bu çalışmada MM' deki p53 ve PUMA ekspresyonlarını değerlendirmeyi ve bu ekspresyonların $\mathrm{MM}^{\prime}$ nin patogenezine ve klinik sonuçlarına etkisini araştırmayı amaçladık.

\section{HASTALAR VE YÖNTEM}

Çalışma protokolü Necmettin Erbakan Üniversitesi Tıp Etik Kurulu tarafından onaylanarak hazırlandı ve çalışmaya katılan hastaların yazılı onamları alındı. Çalışmamız, retrospektif olarak 2010-2014 tarihleri arasında Necmettin Erbakan Üniversitesi Meram Tıp Fakültesi Hastanesi Hematoloji Ünitesine başvuran ve MM tanısı koyulan 31 hastada (13 kadın, 18 erkek; ortalama yaş, $65.7 \pm 9.07$ yıl) gerçekleştirildi. Multipl miyelom hastaları içinden sitogenetik sonuçları veya prognostik kriterleri mevcut olan ayrıca tanı anındaki kemik iliği biyopsileri olan ve biyopsi örneklerinde CD 138 pozitif olan hastalar çalışmaya dahil edildi. Hastaların tanı anındaki klinik ve laboratuar bilgileri dosya verilerinden geriye dönük olarak elde edildi. Kemik iliği biyopsileri Necmettin Erbakan Üniversitesi Tıp Fakültesi Patoloji Anabilim Dalı arşivlerinden alındı. Örnekler tekrar değerlendirildi ve p53 ve PUMA için immünohistokimyasal çalışmalar aşağıda açıklandığı gibi yapıldı. Multipı miyelom tanısı konan her bir hasta International Staging System (ISS) ve DURIE-SALMON evreleme sistemlerine göre kategorize edildi. Kontrol grubu olarak ise, kemik iliği yapılmış ve kemik iliği hematopoez bulguları normal kabul edilen 12 birey ( 6 kadın, 6 erkek; ortalama yaş, $60.7 \pm 14.07 \mathrm{yıl})$ çalışmaya alındı.

\section{Immunhistokimyasal metod:}

Multipl miyelom hastalarının tanı anında alınmış kemik iliği biyopsi kesitleri, parafin blok halindeki kemik iliği örneklerinden hazırlandı. Ve örneklerin hepsine immünohistokimyasal boyama uygulandı. Boyama için $5 \mu \mathrm{m}$ doku kesitleri hazırlandı. Kesitler önce deparafinize ve rehidrate edildi. Endojen peroksidaz aktivitesi $15 \mathrm{dk}$ boyunca $\% 80$ metanol, \% 0.5 hidrojen peroksit içeren solusyonda bloke edildi. Ardından $10 \mathrm{mmol} / \mathrm{L}$ sitrat tampon ( $\mathrm{pH} \mathrm{6.0)} \mathrm{ve}$ mikrodalgada $(700 \mathrm{~W}) 15 \mathrm{dk}$ muamele edildi. Oda ısısında 40 dk soğumaya bırakıldı. İmmunhistokimya işlemi öncesinde fosfat tampon tuzunda (PBS) $5 \mathrm{dk}$ yıkandı. Her bir kesit P53 antikoru (A00021.0025 - p53; Clone DO-7, ScyTek) ve PUMA antikoru ([EP512Y], GeneTex, GTX61282) ile 60 dk inkübe edildi. PBS ile yıkandıktan sonra biotin işaretli sekonder antikor ve ardından streptavidin + peroksidaz uygulandı. Kesitler 3,3'diaminobenzidin ve hematoksilen ile boyandı. Hematopoetik hücrelerde sitoplazmik PUMA boyanma ve nükleer p53 boyanma pozitif kabul edildi. PUMA ile boyanan preparatlar boyama kuvvetlerine göre hafif, orta ve güçlü olarak sınıflandırıldı. Ayrıca PUMA ve p53 pozitifliği saptanan örneklerin boyanma yaygınlığı derecelendirildi.

\section{Istatiksel metod:}

İstatistiksel analiz, Sosyal Bilimler için İstatistik Paketi versiyon 15 (SPSS Inc., Chicago, IL, ABD) ile yapıldı. Sürekli değişkenlerin karşılaştırılması için T testi ve ANOVA kullanıldı. Sürekli değişkenler ortalama, standart sapma, (min, max, medyan) şeklinde, kategorik değişkenler yüzdeler kullanılarak verildi. Ki kare testi kullanıldı ve anlamlılık düzeyi $p<0.05$ olarak kabul edildi.

\section{BULGULAR}

Hastaların demografik, klinik özellikleri ve biyokimyasal parametreleri Tablo 1 'de gösterilmiştir. Durie-Salmonevreleme sistemine; göre hastalarımızın 11 'i (\%35) evre 2A, 1' i (\%3) evre 2B, 12' si (\%39) evre $3 A$ ve 7 ' si (\%23) 3B idi. Beta 2 mikroglobulin sonucu bulunmayan 2 hasta ISS evreleme sistemine göre evrelendirilemedi. Diğer hastalarımızın 6' sı ( \%21) ISS evreleme sistemine göre evre 1, 11' i (\%38) evre 2, 12' si (\%41) evre 3 idi. İmmunglobulin alt gruplarına göre hastalarımızın 24' ü Ig G miyelom, 3' ü Ig A miyelom, 4 tanesi ise asekretuar miyelomdu. Tanı anında immunglobulin düzey ortalaması 49.642 \pm 26.19 (mg/dl) idi. Hastalarımızın serum ve idrar immun elektroforez değerlendirilmesinde 21' inde (\%68) kappa, 9' unda (\%29) lambda monoklonal proteini saptandı. Tanı anında hastalarımızın $25^{\prime}$ inde (\%81) litik lezyon, 7 tanesinde (\%23) ise plazmasitom bulumaktaydı. Hastaların sitogenetik analizinde 
Tablo 1. Hastaların demografik, klinik özellikleri ve laboratuar parametreleri.

\begin{tabular}{ll}
\hline Parametreler & Multipl Miyelom Hastaları $(\mathbf{n = 3 1 )}$ \\
\hline Kadın/Erkek & $13 / 18$ \\
Yaş & $65,74 \pm 9$ \\
$\mathrm{Hgb}$ & $10,09 \pm 1,95$ \\
$\mathrm{Neu}$ & $3,96 \pm 2,43$ \\
$\mathrm{Wbc}$ & $6,68 \pm 3,27$ \\
$\mathrm{PIt}$ & $231,42 \pm 98,41$ \\
Sedimantasyon & $72,58 \pm 41,61$ \\
Albumin & $3,21 \pm 0,65$ \\
Total protein & $9,11 \pm 2,38$ \\
Kreatinin & $1,46 \pm 1,12$ \\
Kalsiyum & $9,17 \pm 1,42$ \\
Beta-2 mikroglobulin & $7,12 \pm 6,58$ \\
Durie-Salmon evre & Evre $2 \mathrm{~A}=11(\% 35)$ \\
& Evre $2 \mathrm{~B}=1(\% 3)$ \\
& Evre $3 \mathrm{~A}=12(\% 39)$ \\
ISS Evre & Evre $3 \mathrm{~B}=7(\% 23)$ \\
& Evre $1=6(\% 21)$ \\
& Evre $2=11(\% 38)$ \\
& Evre $3=12(\% 41)$ \\
\hline
\end{tabular}

ise; 29' unda normal karyotip saptanırken 2' sinde y kromozom kaybı saptandı. FISH taramasında ise; 14 hastanın FISH sonucu normal iken 5 hastada $13 q 14.3$ ve 1 hastada p53 gen bölgelerinde delesyon izlendi. $\mathrm{t}(4,14) 2, \mathrm{t}(6,14) 3, \mathrm{t}(11,14) 4$ ve $\mathrm{t}(14,20) 2$ hastada görüldü. Ayrıca birer hastada CKS1B gen amplifikasyonu, IGH/BREAKAPART (14. Kromozom üzerinde yeniden düzenlenme) ve CBFB/MYH11 gen füzyonu tespit edildi. Kemik iliği biyopsi örneklerinde p53 nükleer (Şekil 1) ve PUMA sitoplazmik (Şekil 2) boyama paterni gösterdi. Kontrol grubunda p53 ve PUMA ile boyama olmazken hasta grubumuzda 8 hastada p53 ile boyama, 28 hastada PUMA ile boyama saptandı (Tablo 2). Hastaların 6' sı hem p53 hem PUMA beraber boyanma özelliği gösterdi.

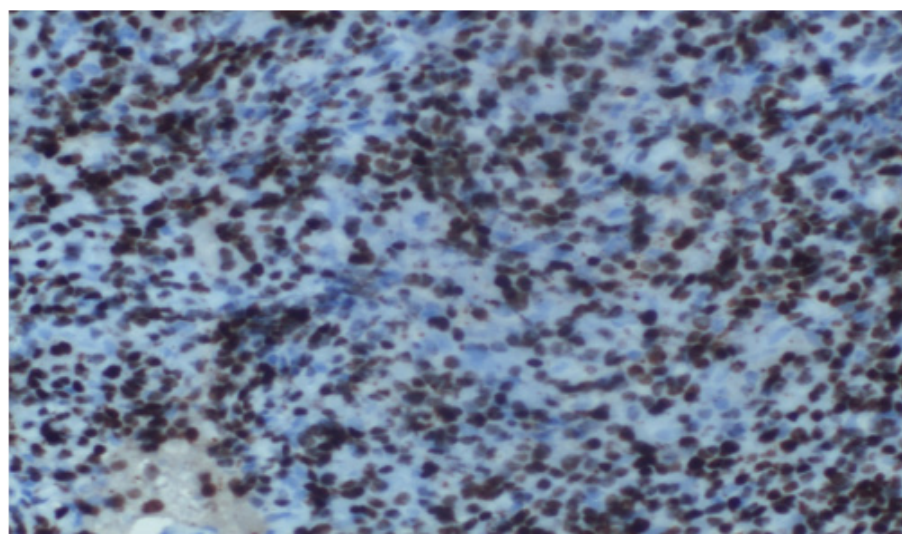

Şekil 1. P53 pozitif boyanan MM kemik iliği örneği

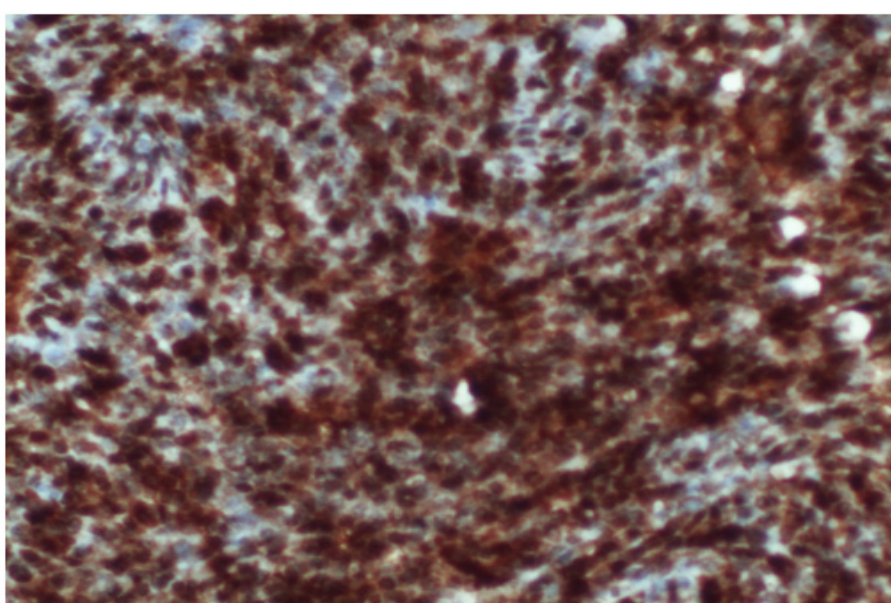

Şekil 2. PUMA pozitif boyanan MM kemik iliği örneği

Hastalığın evresi, anemi, nötropeni, trombositopeni, hipoalbuminemi, kreatinin yüksekliği, Beta-2 mikroglobulin yüksekliği, plazmositom veya litik lezyon varlığı gibi klinik parametreler ile PUMA boyanma kuvveti arasında anlamlı bir ilişki bulunamadı.Hastalarımızın tanı anındaki kemik iliği biyopsisindeki plazma hücre oranları ortalama \% $51.42 \pm 27.616$ idi. Plazma hücre oranı arttıkça PUMA boyanma kuvvetinin arttığı gözlendi. Ancak aralarında istatiksel olarak anlamlı bir ilişki bulunamadı $(p=0.385)$ (Şekil 3).

\section{TARTIŞMA}

Çalışmamız sonucunda birkaç farklı ana bulgular elde edilmiştir. İlk olarak, Multipl miyelomda normal bireylere göre daha yüksek oranda p53 ve PUMA pozitifliği bulunması, miyelomda artmış apopitozisin bir göstergesidir. İkinci ana bulgumuz, PUMA pozitifliğinin tanı anında p53 pozitifliğine kıyasla daha fazla olması miyelomda PUMA' nın p53 dışı nedenlerle harekete geçtiğini göstermektedir. Üçüncü olarak, PUMA boyanma kuvveti ile kemik iliği plazma hücresi arasında istatiksel olarak anlamlı olmasa da bir ilişki görülmektedir. Son olarak ise; PUMA oranları miyelom hastalarında, normale göre anlamlı derecede yüksekti. Bu nedenle, özellikle tanı zorluğu çekilen durumlarda PUMA'nın immünohistokimyasal yardımcı

Table 2. Hastaların ve kontrol grubunun PUMA ve p53 boyanma sıklığı.

\begin{tabular}{llll}
\hline Boya & MM & Kontrol grubu & p \\
\hline p53 & 8 & 0 & 0.000 \\
PUMA & 28 & 0 & 0.000 \\
\hline
\end{tabular}




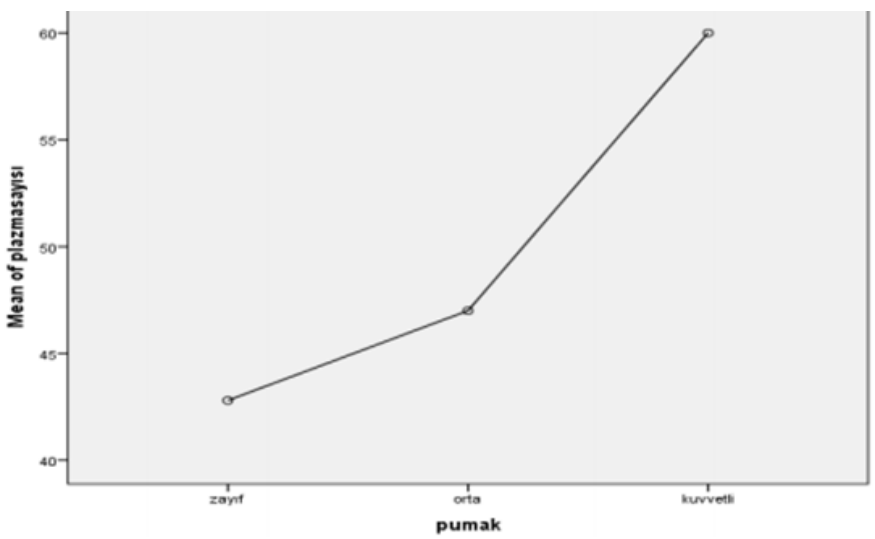

Şekil 3. Plazma oranı ile PUMA boyanma kuvvet karşılaştırılması

test olarak kullanılabileceğini düşünmekteyiz.

Multipl miyelom lenfoplazmaositer hücrelerin neoplastik monoklonal artışı ile karakterize bir hastalıktır. Hastalığın patogenezinde sitogenetik anomaliler, kronik antijen sunumu, apopitotik yoldaki mutasyonlar suçlanmasına rağmen halen tam bir netlik söz konusu değildir (7). Multipl miyelom gibi hücre döngüsü yavaş tümörlerin patogonezinde kronik antijen sunumu önemlidir. Romatoid artritte miyelom sıklığının artması, HIV ve HSV gibi viral uyarının hastalığın patogenezinde rol oynabileceğini gösteren çalışmalar bu hipotezi desteklemektedir (8-9). MM patogenezinde rolü olan bir diğer neden de sitogenetik anomalilerdir. Hastaların yaklaşık \%30-50 kromozamal bozukluk gözükmektedir. Bu oran hastalığın erken evrelerinde daha az ilerleyen evrelerinde daha yüksek oranlarda gözükebilmektedir. Olguların büyük bir bölümünde tek bir kromozomal anormallik olmamakla beraber, çoğunda hiperdiploidi monozomi 13 tetrazomi 9 gibi sayısal anormallik vardır (10-11).

Ancak son zamanlarda miyelom etyopatogenezisinde ön plana çıkan nedenler apopitotik yolda ki mutasyonlardır (12). Apopitozis programlı hücre ölümüdür. DNA ve/veya proteinlerde hasar geldiği zaman birincil hücresel cevap hasarın düzeltilmesidir. Hasar ciddi ise programlı hücre ölümü ile ortadan kaldırılır. Bu süreci kontrol eden faktör p53' tür. Sağlıklı bireylerde transkripsiyon faktörü olarak görev yapan p53' ün hasar meydana geldiği zaman düzeyi artar ve hücre apopitozise gider (13). P53 Bcl-2 aracılığıyla apopitozisi gerçekleştirmektedir. P53 mutasyonu Multipl miyelomda tanı sırasında nadiren mevcut olup genellikle yüksek riskli ve ileri evre miyelom olgularında görülmektedir (14). Bizim çalışmamızda da tanı anında hastaların 8' inde p53 pozitifliği saptandı. Bu bulgu tanı esnasında p53 mutasyonun daha az olması ile ilişkili olabilir.

PUMA ise $\mathrm{Bcl}-2$ ailesi üyelerinden $\mathrm{BH}-3$ subgrubu arasında olup potent öldürücülerinden biridir. PUMA sitoplazmik p53'ün antiapopitotik Bcl-XL'den ayrılmasını sağlayarak p53'ün proapopitotik Bax'ı aktive etmesini sağlar ve mitokondri dış membran permeabilitesini arttırıp apopitozisi gerçekleştirir. PUMA p53, iskemi, DNA hasarı gibi nedenlerle indüklenerek saatler içerisinde apopitozise neden olur (15). Çalışmamızda da; tanı anında hastaların 28' inde PUMA pozitifliği saptandı. Bu durum miyelom etyopatogenezinde apopitozisin önemli bir rol aldığını düşündürmektedir. Aynı zamanda; PUMA pozitifliğinin p53 pozitifliğine oranla daha yüksek oranda pozitif bulunması ise hastalığın erken evrelerinde p53 bağımsız nongenotoksik nedenlerle PUMA' nın indüklenerek Multipl miyelom patogenezine katkıda bulunduğunu düşündürmektedir.

Normal yaşam döngüsünde kök hücrelerinin varlığının idame ettirilmesi ve tümor oluşumunun engellenmesi içinapopitozis mutlakagereklidir. Defektif apopitozis olan hastalıklarda özellikle PUMA aracılıklı apopitozise hiperproliferasyon ve rejenerasyonlar, malign transformasyon gelişimini kolaylaştırabilir. Qui et al. (16) PUMA bağımlı apopitozisin, kompansatuar hiperproliferasyon ile hepatokarsinogenezi arttıtdığını göstermişlerdir. Yu et al. (6) yaptığı çalışmada PUMA eksikliğinin radyasyona karşı hematopoetik hücreleri koruyucu etkisi gösterilmiştir. Raza et al. (17) yaptığı çalışma da MDS' de kemik iliği parankimal ve stromal hücrelerde apopitozis olduğunu fakat lösemik transformasyon gösteren hücrelerde olmadığını göstermişlerdir. Bu da; PUMA' ya bağlı apopitozisin normal hücrelerde klonal hücrelere kıyasla daha fazla olduğunu düşündürmektedir. Çalışmamıza katılan hastaların kemik iliğinde plazma hücre oranı arttıkça PUMA boyanma kuvvetinin arttığı gözlendi. Ancak aralarında istatiksel olarak anlamlı bir ilişki bulunamadı $(p=0.385)$. Bu durum PUMA ekspresyonlarının apopitozise dirençli plazma hücre oluşumuna neden olabileceğini akla getirmektedir. Bizim çalışmamızın bazı sınırlamalar bulunmaktadır. İlk olarak, çalışmamız tek merkezli bir çalışmadır ve örneklem büyüklüğü nispeten azd ır. İkincisi; çalışmaya kayıtlı tüm hastalarımızın Türk olması, sonuçlarımızın milletler arasındaki farklılıklar nedeniyle tüm hastalara uygulanamayacağını düşündürebilir. 
Çıkar Çatışması: Çalışmada herhangi bir çıkar çatışması yoktur.

Finansal Çıkar Çatışması: Çalışmada herhangi bir finansal çıkar çatışması yoktur.

Yazışma Adresi: İsmail Baloğlu, Necmettin Erbakan Universitesi, Iç hastalıkları Anabilim Dalı, Nefroloji Bilim Dalı Konya

e-mail: i_baloglu@hotmail.com

\section{KAYNAKLAR}

1. Kyle RA, Gertz MA, Witzig TE, et al. Review of 1027 patients with newly diagnosed multiple myeloma. Mayo Clin Proc 2003;78(1):21-33.

2. Yoshida Y. The role of apoptosis in MDS; in Steensma DP (ed): Myelodysplastic syndromes: Pathobiology and clinical management. Informa healthcare, 2009, pp 107-25.

3. Jabbour AM, Gordon L, Daunt CP, et al. p53-Dependent transcriptional responses to interleukin-3 signaling. Plos One 2012;7(2):e31428.

4. Gordon M. Stem cell and hematopoezis. In: Hoffbrand AV, Catovsky D, Tuddenham E (eds): Postgraduate Haematology. Blackwell publishing, 2005, pp 1-12.

5. Jabbour AM, Daunt CP, Green BD, et al. Myeloid progenitor cells lacking p53 exhibit delayed up-regulation of Puma and prolonged survival after cytokine deprivation. Blood 2010;115(2):344-52.

6. Yu J, Zhang L. No PUMA, no death: Implications for p53dependent apoptosis. Cancer Cell 2003;4(4):248-9.

7. Loth TS, Perrotta AL, Lima J, et al. Genetic aspects of familial multiple myeloma. Mil Med 1991;156(8):430-3.

8. Isomaki HA, Hakulinen $T$, Joutsenlahti $U$. Excess risk of lymphomas, leukemia and myeloma in patients with rheumatoid arthritis. J Chronic Dis 1978;31(11):691-6.

9. Berenson JR, Vescio RA. HHV-8 is present in multiple myeloma patients. Blood 1999;93(10):3157-9; discussion 3164-56.

10. Hallek M, Bergsagel PL, Anderson KC. Multiple myeloma: Increasing evidence for a multistep transformation process. Blood 1998;91(1):3-21.

11. Taniwaki M, Nishida K, Ueda $Y$, et al. Non-random chromosal rearrangements and their implications in clinical features and outcome of multiple myeloma and plasma cell leukemia. Leuk Lymphoma 1996;21(1-2):25-30.

12. Feinman R, Sawyer J, Hardin J, et al. Cytogenetics and moleculer genetics in multiple myeloma. Hematol Oncol Clin North Am 1997;11(1):1-25.

13. Ryan KM. p53 and autophagy in cancer: Guardian of the genome meets guardian of the proteome. Eur $\mathrm{J}$ Cancer 2011;47(1):44-50.

14. Liu P, Leong $T$, Quam $L$, et al. Activating mutations of $\mathrm{N}$ and Kras in multiple myeloma show different associations: Analysis of the Eastern Cooperative Oncology Group Phase III Trial. Blood 1996;88(7):2699-706.

15. $\mathrm{Yu}$ J, Zhang L. PUMA, potent killer with or without p53. Oncogene 2008;27 Suppl 1:S71-83

16. Qiu W, Wang X, Leibowitz B, et al. PUMA-mediated apoptosis drives chemical hepatocarcinogenesis in mice. Hepatology 2011;54(4):1249-58.

17. Raza A, Gezer S, Mundle S, et al. Apoptosis in bone marrow biopsy samples involving stromal and hematopoietic cells in 50 patients with myelodysplastic syndromes. Blood 1995;86(1):268-76. 